\title{
The Impact of Basel III on Financial Markets
}

\section{Will a combination of structural flaws and illogical, mathematically inconsistent rules make matters worse?}

BY JOEY CHAN, CFA, AND STEPHEN HORAN, CFA, CIPM

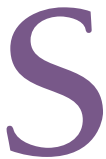

evere economic crises are usually associated with banking sector distress. Because banks are highly leveraged, bank capital can be wiped out quickly when asset quality and value deteriorate during a crisis. A devastated banking sector jeopardizes the payment system (which is crucial to the smooth operation of the economy), the provision of liquidity, and the extension of credit, all of which can lead to a broader economic recession. Risks from the banking system can spread to sovereigns as governments increase their debts to rescue the economy and the systemically important banks. Therefore, it is imperative for policymakers to improve resilience of the banking sector against shocks.

In response to the global financial crisis, the G20 nations and the Basel Committee on Banking Supervision (BCBS) released Basel III, a package of reforms to the existing Basel II regime for banking regulation. Basel III has three principal aims: (1) to boost the banking sector's ability to absorb shocks arising from financial and economic stress, (2) to improve risk management and governance, and (3) to strengthen banks' transparency and disclosure.
To be effective, these regulations will require all countries to work together to implement the "minimum" standards. Otherwise, institutions are likely to engage in "regulatory arbitrage." Under Basel III, similar to Basel I and II, countries can still choose to implement tighter standards tailored to their idiosyncratic national needs. Unlike Basel I and II, however, Basel III attempts to be more comprehensive and consists of reforms addressing risks at the individual financial institutions and risks at the systemic level.

Exhibit 1 presents the core of the Basel III framework in broad strokes. Many of these requirements, especially those related to capital and liquidity, are tailored to the nature of the financial institutions' assets and liabilities.

From the perspective of investors, the main concern is how new requirements will affect equity markets, bond markets, over-the-counter (OTC) derivatives, and trade finance. Unfortunately, implementation of the proposed package is likely to come with many potential drawbacks.

\section{Implications for Equity Markets}

According to a McKinsey paper in September 2011, banks in Europe and the U.S. will need an additional US\$1.5 trillion in equity by 2015 when the requirement of 4.5

\section{Basel III Framework: Highlighting Select Requirements}

\section{Strengthened Capital Base}

- Increasing minimum Tier 1 capital to $6 \%$ of risk-weighted assets (RWA) by 2015 .

- Increasing minimum Common Equity Tier 1 capital to $4.5 \%$ of RWA by 2015 .

- Improving the quality of capital (e.g., tighter definition of Common Equity Tier 1 capital to include only common stocks, retained earnings, and other comprehensive income).

- Creating capital conservation buffer for use during a financial crisis and economic distress. (Starting from $0.625 \%$ of RWA in 2016 and increasing to $2.5 \%$ of RWA by 2019.)
Liquidity Requirements

- Setting a minimum liquidity coverage ratio (LCR) to ensure banks have sufficient high-quality liquid assets for expected net cash outflows over a 30-day period stress scenario.

- Setting a minimum net stable fund ratio (NSFR) to ensure that assets at greater risk of suffering a one-year stress event are matched with longerterm sources of financing.
Governance \& Systemic Risk Mitigation

- Creating firm-wide governance and risk management.

- Requiring sound compensation practices.

- Widening coverage of risks (e.g., higher capital requirements for securitization exposure, counterparty credit risk, OTC activities, etc.).

- Creating countercyclical capital buffer to mitigate systemic risk during a financial crisis and economic distress.

- Setting maximum leverage ratios to prevent excess leverage in good times and reduce the deleveraging dynamic in periods of stress.

- Identifying global systemically important banks (G-SIBs) for special treatment (e.g., greater loss absorbency, more intense supervisory oversight, stronger resolution, reducing their systemic importance over time, etc.). 
$\checkmark$ percent of Common Equity Tier 1 capital kicks in. Therefore, banks are expected to raise more capital through equity market issuance. However, since 2005, the average annual equity issuance for eurozone banks has been in the range of $€ 20$ billion to $€ 50$ billion. The corresponding worldwide equity issuance amount is in the range of US\$50 billion to US\$150 billion. Markets would have a hard time absorbing the new issuance before 2015, even though the banks can reduce external capital requirements by increasing retained earnings, which would reduce dividends.

How stock prices of banks will be affected by Basel III is more contentious. Although many market observers believe that the capital and liquidity requirements are likely to substantially reduce profitability of banks, some experts argue that all things being equal, bank stocks may benefit from higher capital ratios if the market places a greater value on financial stability. The net impact depends on how the possible profits loss from a small capital base compares with the marginal reduction in expected costs of financial distress. It is not easy to determine ex ante.

For the broader equity markets, higher capital reserves increase costs of capital and reduce available funds for lending. In effect, setting leverage ratios caps the bank's scale of business. Limiting leverage and increasing risk weights (see below) discourages prime lending and long-term lending. It may also increase interest rates, making equity financing look relatively more attractive than debt financing for firms in the product markets. Deleveraged capital structures in the product markets will reduce the risk and return on equity, and lower earnings per share for both the banking sector and the broader stock market - assuming that aggregate earnings potential remains at about the same level.

Banks may alternatively choose to shrink their loan base rather than increasing equity, but that will have the same effect. Either way, Basel III is likely to exert downward pressure on the broader equity markets in the coming years.

\section{Implications for Bond Markets}

Global bonds markets will likely be severely impacted by the introduction of the new liquidity requirements - the liquidity coverage ratio (LCR), which measures the sufficiency of liquid assets to satisfy short-term liquidity needs under a stress-test, and net stable fund ratio (NSFR), which measures the sufficiency of long-term stable financing sources to fund long-term illiquid assets.

Banks will favor holding assets that satisfy LCR's liquid-asset criteria and be discouraged from using funding sources with potentially high run-off rates, such as structured investment vehicles (SIV) and special-purpose vehicles (SPV). Because the LCR has a bias towards banks holding government bonds, covered bonds, and high-quality corporate bonds, demand will decrease for less-liquid assets, such as securitized assets and lower-quality corporate bonds. Banks' preference for holding assets that are considered liquid under LCR will shift investors' return on particular market segments and affect credit spreads.
Banks are likely to adopt a two-pronged approach of amassing liquid assets and at the same time scaling down their business operations that are more susceptible to liquidity risks. For example, they will have an incentive to raise capital through retail deposits, repurchase agreements, and stable credit corporate facilities because these types of assets are assigned lower 30-day runoff rates in the LCR calculation.

To the extent that banks hold less-liquid assets, they will be required to secure more stable funding and increase the proportion of longer-term debts in order to reduce the maturity mismatch and maintain the minimum NSFR. This accounts for the popularity of the European Central Bank's (ECB's) recent program of offering three-year loans to banks. Banks borrowed $€ 500$ billion, enough to refinance almost two-thirds of the debt they have maturing over the next year. The banks' additional demand for longer-term financing will compete with other borrowers in the bond market, potentially driving up the yields on bank bonds once the central bank's cheap money is removed from the market.

To curb funding costs, banks will try to raise more retail deposits, especially because these are treated favorably in the LCR calculation. But such deposits are in limited supply, particularly in jurisdictions where banks have to compete for retail savings with insurance companies and pension funds. Accordingly, banks are likely to secure funding through covered bonds or unsecured bonds with longer maturity.

Bond markets will expand as a result of increased supply and the higher yields when the ECB finally steps back from its role as a primary lender. The improved market liquidity of long-term bonds may make short-term investors more willing to consider longer-term investments. To whet investor appetite, banks may have to issue more collateralized bonds with simpler structures and higher transparency. Furthermore, unlike mortgage-backed securities (MBS), covered bonds are acceptable for LCR, which makes them attractive to banks. For MBS to increase the chance of gaining LCR recognition, there should be a highly liquid market coupled with improved transparency.

New regulations giving authorities more latitude to handle failing institutions might also affect bond yields. Investors may be concerned that they will be required to share the burden in the event of a failure. Bank bond holders may not be willing to accept the increased political risks without an adequate rise in bond yields.

Higher capital adequacy is likely to increase financial system stability and encourage a more stable macro-environment for bonds. Therefore, more stringent banking regulations are likely to reduce risks for bond investors.

\section{Implications for OTC Derivatives}

Derivatives markets have started to factor the impact of Basel III in transactions and pricing.

Basel III capital requirements are focused on controlling 
counterparty risk and thus depend on whether banks trade through a derivatives dealer or a central clearing counterparty (CCP).

When a bank enters into under-collateralized derivatives trades with dealers, it assumes counterparty risk. Basel III creates a liability for such trades and mandates a high capital charge. If a bank trades through a CCP, the capital charge will be a mere 2 percent, which would be extremely attractive to the banks.

In addition to counterparty risk, Basel III capital requirements attempt to distinguish between hedging and speculative positions. Risk weightings for CCP positions are applied only to a bank's "loan equivalent amount" of derivatives exposure to a counterparty, which is ascertained after netting out the derivatives exposures. Allowances for netting will encourage central clearing for more bilateral OTC derivatives.

Nevertheless, the "loan equivalent amount" of an exposure after netting must be included in total exposures. Repo and off-balance-sheet commitments must also be counted towards this total and are assigned a 100 percent credit conversion factor. Off-balance-sheet commitments that are unconditionally cancellable carry only a 10 percent credit conversion factor. Whether the end-client is a financial institution, trading OTC derivatives with a CCP will be relatively attractive because the capital charge is much lower.

Under Basel III, either collateral will have to be posted by end-clients to the CCP or bank fees will have to increase to compensate for banks locking up their capital to supply liquidity for the non-cleared OTC derivatives transactions.

Posting non-cash collateral on a CCP is likely to be less costly. The dilemma is that most clients, such as airlines, energy companies and insurance firms, do not have sufficient non-cash collaterals for the CCP. These clients will have to acquire permitted collateral, such as government bonds, or enter into a collateral-conversion/collateral-upgrade trade (which is less cash demanding, though not without its own cost).

Certain assets (such as equities, corporate bonds, warrants, and other tradable products that are not acceptable as collateral by a CCP but otherwise have value in the market), may be used in a collateral-conversion trade. The asset owner can enter into a securities lending or repo transaction and receive treasury securities that can be pledged to the CCP.

The market for collateral conversions has been proliferating, mainly with banks as service providers. A CCP can also provide the same service to reduce complexity and give a one-stop solution to clients who are only making fewer trades. But companies holding large and ongoing OTC derivatives positions, such as insurance or energy companies, may prefer a competitive market that offers better pricing. In any event, banks facilitating collateral conversion are well positioned to benefit from the proliferation of collateral-conversion transactions.

Similarly, to economize the regulatory costs, banks try to warehouse their illiquid securities by posting them as collateral assets to the OTC swap transactions with exchange-traded funds (ETFs). This practice explains the growing popularity of swap-based synthetic ETFs.

No matter how institutions post collateral, the cost of trading OTC derivatives will rise. The cost is likely to be higher for dealer trades as opposed to CCP trades. In the long run, CCPs will evolve to be credit neutral and the least expensive means for market participants' hedging and investing needs. Changes likely will be reflected soon in OTC derivatives agreements.

\section{Implications for Trade Finance}

One of the culprits of the recent financial crisis was securitization, a process by which banks move their assets off balance sheet in order to economize the regulatory capital charge. To address this problem, Basel III has increased the risk weighting (i.e., credit conversion factor) assigned to off-balance-sheet items by fivefold-from 20 percent to 100 percent.

In the original proposal, Basel III would treat (among others) standby letters of credit (LCs) and trade letters of credit similar to off-balance-sheet items. The liquidity and leverage requirements do not consider the risk profile of a loan but simply treat LCs in the same manner as a complex derivatives transaction. As a result, banks would be required to hold 100 percent capital against a lending commitment to finance a trade transaction (a fivefold increase over the current 20 percent). Unless the banks can pass on their increased costs, trade financing will be far less attractive, and they may focus on other businesses and limit their trade credit exposures.

With increased costs of LCs, the trade-financing market is likely to deteriorate as exporters find other less efficient alternatives, such as open account terms, forfeiting, or other forms of unsecured financing. Already, banks are pulling back their services in this area. Because LCs are usually used for trading with emerging markets, these economies may be hurt the most if financing means other than LCs are used. In addition, companies doing business with the developing economies will have to scrutinize more closely the sovereign, geopolitical, and counterparty risks. Similarly, small and medium exporters are likely to be hurt more than large exporters who can diversify many of these risks.

These rules have been severely criticized by tradefinancing professionals because LCs, unlike other off-balance-sheet items, are traditionally low-risk products for banks. The rules may actually encourage rather than discourage risk taking by treating low-risk trade credit in the same way as higher-risk transactions that have much higher profit potential. According to the International Chamber of Commerce, LCs represent approximately 20 percent of world trade and are vital to the world economy. LCs are 
I an effective means to support the underlying economic transactions and should be recognized and encouraged accordingly. Otherwise, nonbank financial companies that do not fall under the purview of Basel III are likely to fill the void and expose the financial system to systemic risk.

Despite the rampant criticisms, not until late October 2011 did the BCBS adopt two technical changes on the capital-adequacy framework to address issues with trade finance. But still, in December 2011, banking association BAFT-IFSA released a list of recommendations for BCBS while a group of 23 banking and trade associations sent a second letter to persuade BCBS to make further changes to the capital requirements for trade finance.

\section{Further Implications for the Banking Sector}

Studies abound on Basel III's implications for the banking sector. This section summarizes some anticipated trends.

Banks are heavily regulated under Basel III and respective national laws, such as the Dodd-Frank Act in the U.S. They are under severe pressure to be more transparent and have simpler balance sheets and capital structures. Thus, banks are likely to reduce certain lending activities to effectively shrink their balance sheets, limit capital market exposure, and eschew structured-product transactions. They will prefer to have their OTC derivatives transactions cleared by CCPs. The regulatory favor bestowed on retail deposits will intensify competition for retail deposits and discourage short-term wholesale funding. Similarly, banks will seek to issue covered bonds for long-term funding because of their treatment in the NSFR calculation. Standards for mortgage lending have already become quite stringent and will remain so, and conventional products and collateral requirements will be more common. Pricing for credit lines, such as home equity credit and credit cards, is likely to increase. Nonbank institutions, outside the ambit of the regulations, will be able to develop cost-effective products that may further weaken the position of the banks and circumvent regulators' attempts to control systemic risk. The banking sector will undergo a consolidation phase to improve efficiency.

\section{Problems with Basel III}

Establishing a minimum leverage ratio, requiring a capital buffer, and combating pro-cyclicality through dynamic provisioning based on expected losses are laudable elements of Basel III. The capital buffer, which is intended to ensure that the leverage ratio is not compromised in crisis situations, seems especially important and will require dividends, share-buyback policies, and executive bonuses to be restrained in good times so banks can build buffers for bad times. Despite the obvious benefits, Basel III raises numerous concerns.

First, Basel III's liquidity rules are primarily focusing on risks at individual institutions and not risks at the systemic level. The International Monetary Fund (IMF) reports that the NSFR would not have signaled problems in the banks that ultimately failed during the recent financial crisis-despite some of these banks failing from poor liquidity management and overuse of short-term wholesale funding. More needs to be done to develop effective measures to mitigate systemic liquidity risks.

Basel III has also been criticized for not resolving the most fundamental problem - that banks can use derivatives (such as CDS) to transform their risks and thus minimize capital costs, even shifting them beyond the bank regulators' jurisdiction-say, to a less-regulated sector, such as insurance, or to a less regulated country.

The shadow banking system continues to compromise the efforts of the regulators. As financial commitments and exposures are shifted around and treated differently from sector to sector and from jurisdiction to jurisdiction, one must question the proper scope of regulatory oversight. Considerations regarding structure of supervision and regulatory process and global coordination among regulators from different jurisdictions can have far-reaching consequences.

Moreover, the process for generating the framework may be hampered by a structural problem. BCBS consists mainly of heads of central banks of developed economies. It has no representation from the broader community or from developing countries that have growing economies and younger populations. Their perception and assessment of risk could be very different.

The group categorized risk and risk models into strategic, market, operational, reputational, credit, and liquidity risk. According to fundamental principles of diversification, risk is not additive. Combining a 99 percent confidence-level calculation for one type of risk with a 99.9 percent confidence level for another risk type is confusing at best and misleading at worst. Risk aggregation requires consideration of how the individual risks are related to each other. The illogical and mathematically inconsistent rules - coupled with different implementation and modeling approaches at the banks - can be puzzling for the boards of the banks. The new rules may be more for regulators and compliance officers than guiding business decisions in the board rooms.

Although some regulations are final, the Basel Committee has not yet completed its work. Most of the Basel III rules will be revised further as more people criticize their suitability. The current timeline is for everything to phase in by 2019, which provides ample opportunity for things to change. For example, there were a number of "final" versions before Basel II was refined to the final June 2006 version. No one knows how much more Basel III will change in the coming years. Conceivably, inefficiencies of the framework may lead to the drafting of Basel IV before Basel III is finalized.

Joey Chan, CFA, is director of planning and programme development and Stephen Horan, CFA, CIPM, is head of university relations and private wealth at CFA Institute. 